\title{
MORE RELIGIOUS, LESS DOGMATIC: Toward a General Framework for Gender Differences in Religion
}

\section{Landon Schnabel ${ }^{1}$ \\ Indiana University-Bloomington}

Last Revised: 2018-04-25

Word Count: 9,830

Tables: 8

\begin{abstract}
:
Gender gaps in religiosity are among the most consistent findings in the social sciences. The literature, however, has typically under-emphasized gender theory, paid insufficient attention to variation across different contexts, and failed to consider styles of religious expression. This study draws on gender theory, brings religion and political attitudes research into dialogue, and explores potential gender differences in religious dogmatism (e.g., religious absolutism, exclusivity, and intolerance). Using U.S. data from the Baylor Religion Survey and cross-national data from the International Social Survey Programme, I demonstrate that women are generally more religious, but less dogmatic. As expected based on gender theory, however, the patterns I uncover are not universal and vary by societal context (i.e., Christian vs. non-Christian nations). I argue that religion appears to be a gendered sphere like any other in which we express our gendered selves, and that gender gaps in religion are the result not of essential differences, but of context-specific gender regimes, religion regimes, and the simultaneous "doing" of both gender and religion.
\end{abstract}

Keywords: Religion; Gender; Politics; Tolerance

\section{THIS IS A DRAFT. PLEASE DO NOT QUOTE OR CIRCULATE WITHOUT AUTHOR PERMISSION.}

\footnotetext{
${ }^{1}$ The author owes special thanks to Art Alderson and especially Brian Powell for their exceptional feedback on this project. He is also grateful to Clem Brooks, Long Doan, Andy Halpern-Manners, Courtney Irby, Trent Mize, Richard Pitt, Sam Perry, Allison Schnable, Cate Taylor, Peggy Thoits, Tom VanHeuvelen, fellow participants in the stratification and inequality workshop at Indiana University, and anonymous reviewers for their insightful comments on earlier drafts. This study was presented at the 2015 meetings of the American Sociological Association and the 2016 meetings of Sociologists for Women in Society and the Society for the Scientific Study of Religion, and as part of the presidential panel on gender and religion at the 2015 meetings of the Association for the Sociology of Religion. It has been recognized by the Altruism, Morality, and Social Solidarity Section of the American Sociological Association, the Midwest Sociological Society, and the American and World Associations for Public Opinion Research. Direct correspondence to Landon Schnabel, Department of Sociology, Indiana University, 744 Ballantine Hall, 1020 E. Kirkwood Ave., Bloomington, IN 47405. Email: lpschnab@indiana.edu.
} 
Women tend to be more religious than men, but are they subsequently more religiously dogmatic? Gender gaps in religiosity are among the most consistent findings in the social sciences (Baker and Whitehead 2016; Miller and Stark 2002; Roth and Kroll 2007). However, the literature is incomplete in three ways. First, key insights from the sociology of gender on the general question of gender differences have been under-emphasized. Second, most relevant studies have focusd on Christian contexts and underemphasized potential variation across other religious contexts. Third, gender differences in styles of religious expression have not been examined. This paper's overarching theoretical argument is that we may not need a new theory specific to religion to explain gender differences in religion, but instead could draw on general gender theories used to explain gender gaps in other areas to understand context-specific gender gaps in religion. I explore this larger framework about religions being gender-typed social structures_and Christianity in particular being feminine-typed — with a more specific question of whether and how women "do religion" differently than men, expecting women to "do Christianity" with more compassion and less dogmatism.

The sociological study of gender and religion emerged in the 1970s and 80s with feminist critiques of religion as patriarchal and later developed into diverse considerations of the varied interconnections between gender and religion (Avishai 2016). But sociologists of gender who study religion and sociologists of religion who study gender have not been in dialogue (Avishai and Irby 2017), and the gender differences in religiosity literature was developed primarily by sociologists of religion who frequently undertheorized gender (Avishai 2016; Avishai, Jafar, and Rinaldo 2015). They often treated gender as an essential characteristic (i.e., sex) rather than conceptualizing it as a dynamic, multidimensional, and context-specific structure, status, and performance (Avishai and Irby 2017; Cornwall 2009; Risman 2004) in the background of all social interaction (Ridgeway 2011). Cornwall (2009), speaking as editor of an issue of the Journal for the Scientific Study of Religion focused on the gender gap in religiosity, said that gender scholars would critique the literature for its 
insufficient application of gender theory. She asserted that religiosity is a gendered construct and, therefore, gendering processes could easily explain gender differences in religiosity (also see Hoffmann 2009). Avishai, Jafar, and Rinaldo (2015), speaking as guest editors of a special issue of Gender \& Society focused on religion and gender (Aune 2015; Avishai et al. 2015; Gerber 2015; Khurshid 2015; Prickett 2015; Zion-Waldoks 2015), similarly argued that religion is a gendered institution, that the literature on religion and gender neglected key gender theories, and that scholars should turn a "gender lens" on religion (Avishai 2016; Baker and Whitehead 2016; Schnabel 2016b). This article builds on theories about gender as a performance, status, and structure and religion as a gendered institution to lay out a framework in which women are more religious and express more caring and tolerant forms of religion because of context-specific gendering processes.

I explore this larger theoretical framework empirically by examining the more specific question of whether women and men "do gender" in religion in ways consistent with how they "do gender" in other social spheres. To do so, I leverage underutilized measures from the U.S. Baylor Religion Survey and the International Social Survey Programme to examine whether, in addition to gender differences in religiosity, there are gender differences in religious dogmatism in the U.S. and crossnationally. I propose and use the following working definition of religious dogmatism: "religious dogmatism" is the tendency for people to think they are cognitively and morally right, others are wrong, and that others should follow their "right" beliefs. ${ }^{1}$ Women are more religious than men across many societies (Freese 2004; Hackett, Murphy, and McClendon 2016; Sullins 2006), and religiosity is consistently linked to religious dogmatism (Allport and Ross 1967; Edgell, Gerteis, and Hartmann 2006; Merino 2010; Meulemann 2013; Putnam and Campbell 2010; Rokeach 1960). But,

\footnotetext{
${ }^{1}$ Rokeach (1954) defined generalized dogmatism as "(a) a relatively closed cognitive organization of beliefs and disbeliefs about reality, (b) organized around a central set of beliefs about absolute authority which, in turn, (c) provides a framework for patterns of intolerance toward others" (p. 195). Similar to Rokeach's $(1954: 194,1960)$ conception of
} 
in "doing gender" differently, women and men may "do religion" in gendered ways (Avishai 2008;

Rao 2015; West and Zimmerman 1987), with women's religious expression being more tolerant and inclusive consistent with gender socialization and gendered norms about women being caring, communitarian, and other-focused (Charles and Bradley 2009; Eagly 1987; Ridgeway 2011). I find that women are, on average, more religious, but less dogmatic. Conversely, men are less religious, but more dogmatic. Indicative of the context-specific nature of gender differences and variation in how religions are gendered, these patterns are most pronounced in Christian contexts.

In the course of applying gender theory to gender gaps in religion, this article answers Cornwall's (2009) appeal to consider how gendering processes may lead to different expressions of religiosity for women and men, Smith et al.'s (2013) recommendation to consider global patterns in religion, and Avishai, Jafar, and Rinaldo's (2015) call to turn a gender lens on religion. The results suggest religion is a gendered sphere like any other in which we negotiate and express our gendered selves, and that religious absolutism and conflict cannot be fully understood separate from gender.

\section{GENDER GAPS IN RELIGIOSITY AND IN POLITICS}

\section{Gender Differences in Religiosity}

Women tend to score higher on commonly available measures of religiosity and orthodoxy (Miller and Stark 2002; Roth and Kroll 2007; Sullins 2006). In some societies, and among some religious groups, however, there are no, or even reverse, gender differences (Hackett et al. 2016; Schnabel 2015; Schnabel, Hackett, and McClendon 2018). But whenever scholars compare the average religiosity of women and men in the United States and many other societies, especially where Christianity predominates, they consistently find that women are more religious than men (Miller and Stark 2002; Roth and Kroll 2007). Although various theories—such as socialization (Collett and

dogmatism as the convergence of "closed cognitive systems, authoritarianism, and intolerance," I deploy dogmatism as a broad term to encompass absolutism, exclusivity, prejudice, intolerance, and "othering." 
Lizardo 2009), social structure and status (Hastings and Lindsay 2013; de Vaus and McAllister 1987), vulnerability (Norris and Inglehart 2011; Walter and Davie 1998), and personality and psychology (Francis 1997; Freese and Montgomery 2007; Thompson 1991)—have been used to explain gender differences in religiosity, risk preferences theory and the assertion of "universal" gender differences have dominated recent debate on the topic.

Risk preferences theory argues that being irreligious is spiritually risky, men are more prone to risky behavior, and therefore men are less religious than women (Miller and Hoffmann 1995). Stark and Miller (Miller and Stark 2002; Stark 2002) attributed risk preferences to biology, arguing that testosterone makes men engage in "risky" behaviors— such as violent crime and not going to church. ${ }^{2}$ More recent research on gender differences in religiosity has focused on debating, nuancing, or refuting the risk preferences approach and no alternative has yet gained traction (Collett and Lizardo 2009; Ellis, Hoskin, and Ratnasingam 2016; Freese and Montgomery 2007; Lizardo and Collett 2009; Roth and Kroll 2007). Some scholars have focused on gendering processes to either build upon or suggest a move beyond religion-specific theories. For example, Collett and Lizardo (2009) argued that risk preference findings could result from socialization processes. Edgell, Frost, and Stewart (2017) suggested a move away from spiritual or existential understandings of risk to a more gender-theory-informed notion of social risk. They suggest that women are expected to be religious and face more social sanctions for being non-religious. Breaking more fully from ideas of risk, Cornwall (2009) suggested that researchers stop examining whether and how risk explains gender differences on standard religiosity measures and instead draw upon gender scholarship to consider how gendering processes may lead to different expressions of religion for women and men. 
The present study shifts the conversation by theorizing in the vein of Collett and Lizardo's (2009) work on gendering processes and Edgell, Frost, and Stewart's (2017) emphasis on social expectations while also following Cornwall's (2009) exhortation to consider different forms of religious expression. To do so, I explore a set of religious beliefs and values that I label religious dogmatism. Dogmatic expressions of religion are intolerant of religious differences, view religious outgroups negatively, and believe in an absolute divine order and/or harsh deity who will punish religious others. In the process of examining potential gender differences in religious dogmatism, this study draws on gender scholarship and bridges the literatures on gender gaps in religiosity and gender gaps in political attitudes to turn a gender lens on religion (Avishai et al. 2015).

\section{Dogmatism and Gender Gaps in Political Attitudes}

Shortly after World War II the study of absolutism, outgroup hatred, and "othering" processes was more central to the field than today. World events motivated sociologists and social psychologists to study aspects of what some call the dark side of humanity: for example, one-dimensional—or dogmatic_ideologies (Marcuse 1964), absolutism (Adorno et al. 1950), intolerance (Stouffer 1955), and linkages between religion and dogmatism (Rokeach 1954, 1960; also see Allport and Ross 1967). Although once predominant in sociology, the study of authoritarianism and general intolerance has, arguably, been sidelined for several decades. Nevertheless, two more recent, and as yet disconnected, research agendas have linked religiosity with intolerance and documented gender gaps in politics.

The relationship between religion and conservative views is complex and contingent on elite framing, information seeking, and partisan identities (Malka et al. 2011, 2012; Malka and Soto 2011), and we should not assume that religiosity will, of necessity, associate with conservative or liberal views (Converse 1964). Nevertheless, some forms of religiousness are strongly associated with

2 This theory relies on Pascal's Wager-a $17^{\text {th }}$ century apologetic argument that asserts a logical person should be religious because of the risk of eternal punishment — to assert that being irreligious is risky (Miller and Hoffman 1995; 
dogmatism (Froese, Bader, and Smith 2008; Merino 2010; Rokeach 1960) and are powerful predictors of conservative stances on diversity and minority rights issues (Olson, Cadge, and Harrison 2006; Powell et al. 2010; Putnam and Campbell 2010; Sherkat et al. 2011). But women, who are more religious than men, are more supportive of minority rights such as same-sex marriage. This presents a potential paradox: Despite being more religious, women may be less religiously dogmatic.

Although questions of religious tolerance have not been considered in the gender differences in religiosity literature, there is a robust literature on gender gaps in politics. U.S. research has found women more politically tolerant (Box-Steffensmeier, DeBoef, and Lin 2004; Olson et al. 2006), more likely to express concern for the well-being of others (Beutel and Marini 1995), and more likely support policies sympathetic to the needs of others, especially the disadvantaged (Beutel and Marini 1995; Eagly et al. 2004). But women can be more intolerant than men toward some political outgroups (e.g., communists) (Golebiowska 1999), and, relevant to the present study, women often believe in literalism (Hoffmann and Bartkowski 2008) and indicate greater social distance from one religious outgroup (atheists) (Edgell, Gerteis, and Hartmann 2006; but see the Edgell et al. 2016 extension that did not replicate this finding). ${ }^{3}$ Similar trends in women being more tolerant and other-focused appear in cross-national research (Inglehart and Norris 1999), with global studies indicating that women are less xenophobic and homophobic than men (Hadler 2012).

Some research links gender gaps in politics to women scoring lower on social dominance, which is preference for inequality among social groups (Pratto, Stallworth, and Sidanius 1997). Other work suggests women's underdog status makes them more aware of and concerned for the status of other structurally-disadvantaged groups (Davis and Robinson 1991; Hunt 1996; Schnabel

Miller and Stark 2002; Stark 2002). 
2018). Simlarly, Eagly and colleagues (2004) focused on the status and situated experiences of women and men to explain the differences in line with Eagly's (1987) previous work, which used gender norms and expectations to explain gender differences more broadly. Eagly et al. (2004) demonstrated that women are more compassionate, committed to equality, and less supportive of group-based dominance. According to them, gender differences in political attitudes parallel gender differences in other communal attitudes and identities, which I aruge includes religion. In other words, general theories of group differences (e.g., the underdog principle and related theories) could be used to account for gender differences in religion.

\section{RELIGION AS A GENDERED STRUCTURE}

Scholars have noted that gender, race, sexuality, politics, and the economy are social structures with individual, interactional, and institutional dimensions (Bonilla-Silva 1997; Risman 2004). Religion, although less frequently discussed in this literature, is likewise a social structure. It is, among other things, an identity that intersects with other identities, a social institution with particular teachings and cultural norms, and a social good that provides social psychological benefits (Schnabel 2017b). Moreover, it is not just a one-day-a-week phenomenon, it is a social-organizing, sense-making, and comfort-providing structure embedded throughout people's lives similar to gender, race, and class (Ammerman 1997; Aune 2015; Khurshid 2015; Schnabel 2016b). In addition to being a social structure by which society is organized, experienced, and made sense of, religion is a gendered social structure (Avishai et al. 2015; Prickett 2015; Whitehead 2013).

Setting aside the question of why religions as social structures first became gendered, it is understandable why something that is gender-imbalanced and potentially seen as more the realm of

\footnotetext{
${ }^{3}$ Although the gender difference was not significant in the replication, it was in the same direction as the previous study (i.e., women indicating more social distance from atheists).
} 
women—which appears to be the case with many religions, especially Christian ones ${ }^{4}$ — could be more appealing to women and less appealing to men (Greve 2014; Schnabel 2017a; Schnabel et al. 2018; Trzebiatowska and Bruce 2012). Occupational segregation highlights how institutional spheres become feminine-typed once enough women join them (Levanon, England, and Allison 2009; Reskin 1991). Likewise, political parties can be seen as more masculine or feminine in the presence of gender cleavages in politics, which then facilitates a mutually reinforcing loop that exaggerates what started as small differences (Messner 2013; Winter 2010). When gender gaps emerge in an institutional context, they reinforce themselves because that setting becomes yet another place to “do gender" (Cornwall 2009; Reskin 1991; Trzebiatowska and Bruce 2012; West and Zimmerman 1987). Women are more likely to be involved in some religions, and the roles women and men play within these religions tend to be different, with men filling more leadership roles and women filling more caring and altruistic roles such as managing children's programming, visitation, and charity work (Edgell 2006). This involvement varies across religious traditions with key differences, for example, in who tends to be more responsible for children's religious socialization (moreso women in Christianity and moreso men in Isalm), and the extent to which women are expected and integrated in public religious engagement (men but not women count toward a quorum in Orthodox Judaism, and women are typically segregated away from men's view in traditional Islam and Judaism).

Christianity and Christians may be viewed as more feminine and less masculine than nonreligious people, ${ }^{5}$ and popular rhetoric_ _ as well as foundational social theory (Marx and Engels 2008; Weber 1963)—suggests Christianity is a feminized "underdog" religion. The "Fight Church"

\footnotetext{
${ }^{4}$ The woman-typing of religion is based on everyday involvement, not leadership positions, which are often dominated by men, and this "feminization" does not mean that religion is good for women (Schnabel 2016a).
} 
phenomenon-pastors hosting and participating in cage-fights at houses of worship to promote muscular Christianity_provides a vivid anecdotal example of some men's view that Christianity is too feminine, sympathetic, and tolerant (Greve 2014). Therefore, in Christian contexts women who are perceived as insufficiently religious could be socially sanctioned as being insufficiently feminine; likewise, men who are perceived as too religious could be sanctioned as being overly feminine (Edgell et al. 2017; Schnabel 2017a; Sherkat and Wilson 1995). Gendered perceptions and expectations about religion may even exaggerate gender gaps with women over-reporting their religiosity due to internalized beliefs about how religious they should be (Brenner 2014).

It should be no surprise, then, that a family-centric, expressive, other-focused, comfortproviding, and feminine-typed structure (i.e., Christian religion) situated in gendered societies demonstrates gender gaps (i.e., the religiosity gender gap and, potentially, a reverse dogmatism gender gap) (Edgell 2006; Gallagher 2003; Schnabel 2017a; Trzebiatowska and Bruce 2012). From the point of view of gender theory, we do not need wholly novel theories to understand why religion, or any other structure or institution, is gendered (Avishai et al. 2015; Cornwall 2009). If doing religion differently, men and women may simply be doing gender as it is practiced and experienced in other gendered spheres such as politics (Avishai 2008; Cadge 2004), another key social structure with gender gaps explained by underdog social status and general gendering processes.

\section{EXPECTATIONS}

If general gendering processes can explain gender differences in religiosity we should expect women and men to do religion in distinctive ways and hold distinctive beliefs in keeping with the roles they play in non-religious spheres, their social status, cultural norms in many societies, broad interactional

\footnotetext{
${ }^{5}$ Pretest findings based on MTurk data for an experimental survey study being conducted by the author demonstrate that MTurk workers view Christians and Christianity as significantly more feminine and significantly less masculine than
} 
and institutional gender processes, and the sociopolitical attitudes women and men hold more generally (Eagly 1987; Edgell 2006; Hall et al. 2012; Prentice and Carranza 2002). In other words, we may expect women and men to express different forms of religion with women being more tolerant, loving, and other-centered in many, but not all, societies because of the context-specific nature of gender and religion as social structures (Charles and Bradley 2009; Eagly 1987; Hyde 2005; Risman 2004).

EXPECTATION 1: Women will be more religious and less dogmatic than men.

Scholars have argued that religion appeals to women because it provides the disadvantaged with security and comfort (Marx and Engels 2008; Norris and Inglehart 2011; Trzebiatowska and Bruce 2012; Weber 1963) and is feminine-typed and more expected of women (Brenner 2014; Edgell et al. 2017; Schutz and Roth 2014). Other research suggests that gender gaps vary by context, highlighting some men's view that Christianity is insufficiently masculine (Greve 2014), that gendered expectations that women should be more religious are most pronounced among Christians (Schnabel 2015; Schnabel et al. 2018), and that Christianity has a strong underdog appeal (Marx and Engels 2008; Schnabel 2016b). Because Christianity is viewed as a feminized "underdog" religion that values compassion and "turning the other cheek" in the face of oppression (Greve 2014; Trzebiatowska and Bruce 2012; Walter and Davie 1998), historically Christian contexts should reveal the largest differences in religiosity and, possibly, the largest reverse gender differences in religious dogmatism.

EXPECTATION 2: Gender differences in religiosity and religious dogmatism will be most pronounced in Christian contexts.

atheists. 


\section{DATA AND METHODS}

I examine these expectations using the U.S. Baylor Religion Survey (BRS) and the International Social Survey Programme (ISSP). The BRS was modeled on the General Social Survey but with the distinctive goal of comprehensively assessing religious attitudes, beliefs, and behaviors. Data were collected from a national random digit dial sample by the Gallup Organization with a 47 percent response rate and final sample of 1,648. Demographic patterns from the 2007 BRS compare favorably to the GSS and auxiliary analyses using questions about religious minorities from the GSS yield similar patterns. Missing data on covariates are handled with multiple imputation. ${ }^{6}$

I then test the same hypothesis—-that women are more religious but less religiously dogmatic — cross-nationally with data from the 2008 International Social Survey Programme religion module that was fielded in 40 countries. $^{7}$ The ISSP is a cross-national collaboration of standardized surveys, each fielded as part of a country's larger random survey of the non-institutionalized adult population. ISSP data provide the opportunity to test Hypothesis 2, which suggests that the proposed pattern of women being more religious but less dogmatic will be most pronounced in Christian contexts. As with the BRS data, missing data on covariates are imputed. ${ }^{8}$

\section{Baylor Religion Survey Measures}

To assesses whether gender differences in dogmatism parallel or diverge from gender differences in religiosity, I first examine gender differences on typical religiosity and belief measures: religious affiliation, religious salience, attendance frequency, prayer frequency, belief in heaven, and view of the Bible. I then examine questions related to religious dogmatism, which I categorize into the

\footnotetext{
${ }^{6}$ Parental status (74 missing cases) and rurality (69) had the most missing data. I present unweighted results—analyses with weights yielded the same patterns.

${ }^{7}$ Australia, Austria, Belgium, Chile, Croatia, Cyprus, Czech Republic, Denmark, Dominican Republic, Finland, France, Germany, Hungary, Ireland, Israel, Italy, Japan, Latvia, Mexico, Netherlands, New Zealand, Norway, Philippines, Poland, Portugal, Russia, Slovak Republic, Slovenia, South Africa, South Korea, Spain, Sweden, Switzerland, Taiwan, Turkey, Ukraine, United Kingdom, United States, Uruguay, and Venezuela.
} 
following groupings based on what is available in the BRS: (1) afterlife exclusivity, (2) fundamentalist identity, and (3) belief in a harsh God who will punish people who are not orthodox/orthoprax (i.e., who do not believe or do the "right" things). Respondents were only asked to answer the afterlife exclusivity questions if they believed in an afterlife.

Gender (woman=1) is the key independent variable. Following previous research on gender differences in religiosity and studies using the BRS (Perry 2014; Schnabel 2016b), I control for key sociodemographic characteristics described in Table 1. I also present models that control for religious salience. ${ }^{9}$

[Table-1]

\section{International Social Survey Programme Measures}

The cross-national analyses again start with standard religiosity measures. I then examine questions related to religious dogmatism, which are categorized under two headings following the measures available in the ISSP: (1) Lack of respect and acceptance of other religions, and (2) negative views of people in other religions. Negative views of people in other religions are based on questions fielded in 20 of the 40 countries about respondents' views of people with various religious affiliations: atheist, Buddhist, Christian, Hindu, Jewish, and Muslim. I create a summated scale $(a=.91)$ of attitudes toward other groups (based upon all the religions that one is not).

Gender is again the key independent variable. Paralleling the U.S.-only analyses, I control for key sociodemographic characteristics available across countries and supported by fit statistics. I also include models with a measure of religious salience.

\section{[Table-2]}

\footnotetext{
${ }^{8}$ I used single imputation was used for the ISSP because Stata's multilevel commands are not compatible with multiple imputation. Listwise sensitivity analyses yielded the same patterns.

${ }^{9}$ Additional analyses with controls for religious affiliation categories along with religious salience yielded the same patterns.
} 


\section{Analytic Strategy}

For the U.S.-only analyses, I first examine gender differences in religiosity and then dogmatism. Alternating Least Squares Optimized Scaling (ALSOS) regression is used for all but the affiliation measure, for which binary logistic regression is used. Ordinal outcome variables—such as religious salience measured from not at all religious $=1$ to very religious $=4$ - do not always have equal spacing between categories. ALSOS is a method for estimating models without making arbitrary and ultimately unjustifiable assumptions about category spacing for ordinal outcomes. ALSOS provides best-fitting estimates of value points and individual vectors and thus transforms categorical data into linear data on which OLS calculations can be made. In other words, ALSOS procedures are used to rescale ordinal dependent variables with empirically meaningful spacing between categories so that, for example, being not at all religious, not too religious, somewhat religious, and very religious are rescaled to values of $1.06,1.67,3.24$, and 3.81 instead of the arbitrary values of $1,2,3$, and 4 . Coefficients for this method can be interpreted similarly to OLS estimates because ALSOS transformation retains the original means and standard deviations of the untransformed variables. The optimal scaling procedure was conducted using Armstrong's ALSOS R package and subsequent regression analysis using the rescaled dependent variables was conducted in Stata. ${ }^{10}$

I follow a similar approach to present the international results, but in parsimonious multilevel models with random-intercepts for country focused on whether individual-level gender differences in religiosity and dogmatism vary by predominant religion (measured by the religious affiliation reported by the largest number of respondents in a given country): Christian, Muslim, Jewish, “other Eastern” (a label created by the ISSP), and no religion (see Adamczyk and Pitt 2009; Schnabel 2016a for similar operationalizations of country-level religious tradition). I use multilevel

\footnotetext{
10 Sensitivity analyses with ordinal logistic and multinomial models demonstrated equivalent patterns.
} 
mixed-effects logistic regression for binary outcomes, multilevel mixed-effects ALSOS regression for ordered outcomes, and linear mixed-effects multi-level regression for continuous outcomes.

\section{RESULTS}

\section{U.S. Analyses}

Table 3 demonstrates women's greater religiosity across standard measures: affiliation, religious salience, attendance, prayer, belief in heaven, view of the Bible, and a standardized scale of these six items. In this and other tables, higher coefficients for gender indicate that women score higher on the measures in question. These data provide the same findings on measures commonly used in previous research and provide a baseline for considering the extent to which religious dogmatism follows, or deviates from, this pattern of women being more religious on commonly-used measures. Further analyses (not shown) demonstrate that these religiosity measures are positively and strongly associated with religious dogmatism (the correlation between the religiosity scale and the dogmatism scale is .57). Therefore, based on that information alone and with no prior knowledge of gender research, we might expect that women, who are more religious, will be more dogmatic.

\section{[Table-3]}

Table 4 presents gender differences on dogmatism measures not examined in the gender differences in religiosity literature. First, women are more inclusive than men in their beliefs about the afterlife. ${ }^{11}$ The bivariate relationship between gender and afterlife exclusivity is significant for all but beliefs about the non-religious: women think that more of their neighbors, more average Americans, more Buddhists, more Muslims, and more Jews will go to heaven than men think will go to heaven. Including sociodemographic controls does not explain away the patterns, and if anything leads to slightly, but not significantly, larger coefficients. When women's greater overall religious salience is accounted for, women are also significantly more likely to think that non-religious people 
will go to heaven. So while women are more religious, they are also more inclusive than men in their afterlife beliefs. ${ }^{12}$ This pattern indicates that, in keeping with the notion that women in our gendered society are generally more accepting and other-centered, women's religious beliefs are generally more positive toward other people than are men's.

\section{[Table-4]}

Shifting from views of others to self-identification, Table 4 demonstrates no bivariate gender differences in holding a dogmatic identity, but men are more likely than women to hold dogmatic identities when accounting for religious salience. Additional analyses presented in Table A1 demonstrate that women tend toward being more likely to identify with left-of-center identities, with women significantly more likely to identify as theologically liberal.

Table 4 also demonstrates that women hold less dogmatic God concepts. In the bivariate model, women are less likely than men to believe in a God that is punishing, severe, wrathful, and likely to hand out terrible woes, small punishments, and cause tragedies for not following said divinity correctly. When accounting for religious salience, which is associated with harsher views of God, women are also less likely to believe in an angry God that requires war. In addition to being less likely to believe in harsh and punishing views of God, women are more likely to believe in a caring and loving God as measured by God as "loving," "kind," "friendly," "forgiving," and "concerned about the well-being of the world" (see Table A1). These gendered views about God mean that women have a more caring and comforting conceptualization of God to parallel their more inclusive and less dogmatic views about others and themselves. In addition to women being less dogmatic across individual measures, women are less dogmatic on scales that combine each subsection of measures and a scale of all the dogmatism measures listed above.

\footnotetext{
${ }^{11}$ Additional results for scales parallel and support the findings for individual items presented here.
} 
Supplemental analyses with interaction terms demonstrate that although much of the pattern of women being more religious but less dogmatic is a gender main effect (women generally tend toward less dogmatism than men across levels of religiosity), gender differences in dogmatism tend to be largest among the moderately religious. ${ }^{13}$ Additional subsample analyses demonstrate that the pattern of women being more religious but less dogmatic operates clearly among Christians, but the small sample of people in other religions (less than nine percent of the BRS sample) operates differently, with non-significant coefficients in the opposite directions. ${ }^{14}$

To explore the social correlates and implications of dogmatism, I considered the relationship between religiousness and dogmatism (each measured with a scale of all the relevant measures listed above_as noted previously, these scales are correlated with one another at .57) and general political orientation (see Table A2), as well as some individual attitudinal items frequently studied in relation to religion (e.g., abortion and same-sex relationship attitudes). I found that both religiousness and dogmatism are strongly and independently linked to more conservative views, and that reverse gender differences on these two scales complicate gender differences in political values (see Table A2). ${ }^{15}$

12 Additional analyses demonstrate that women are about twice as likely as men to say that everyone from each group will go to heaven (i.e., belief in universalism).

13 Additional analyses considered gender differences in dogmatism by level of religiosity. Higher religious salience is associated with more dogmatism for both men and women across measures, but women generally tend toward less dogmatism than men across levels of religious salience. Gender differences in dogmatism are typically largest among the somewhat religious, which is the largest religious category for both women (42 percent of women) and men (43 percent of men). This pattern of moderately religious women doing their religion in a more tolerant way parallels a similar finding in the same-sex marriage attitudes literature: women's greater acceptance of same-sex relationships is largest among political moderates (Powell et al. 2010).

${ }^{14}$ Additional analyses using the GSS, which has more limited measures of religious dogmatism, parallel the BRS findings: women have more positive feelings than men toward religious minorities (Jews and Muslims), and men are more prone to black and white thinking.

15 Consistent with other research (Schnabel 2017b), women's greater religiousness strongly suppresses what would otherwise be larger gender differences in politics. Women's lesser dogmatism weakly amplifies gender differences in politics. 


\section{Cross-National Analyses}

The U.S. analyses demonstrated that women, while more religious than men, have religious beliefs that are generally less dogmatic. We should not assume, however, that gender operates in the same way across cultural contexts or that a finding based on patterns in the U.S., where most people are Christian, is indicative of a broader social pattern. Therefore, I next examine general patterns across countries, and then consider whether and how the patterns vary across religiocultural contexts.

Table 5 demonstrates that the U.S. pattern of women being more religious but less dogmatic does apply to the 40 ISSP countries collectively. ${ }^{16}$ In multilevel models, women are more likely to be religiously affiliated, say religion is more important in their lives, attend and pray more frequently, and are more likely to believe in an afterlife. Men, however, are more likely to say that other religions do not need to be respected, more likely to reject marriages of family members outside their religious group, and more likely to dislike people in religions different han their own. But just because women are more religious but men more dogmatic across countries does not mean the patterns apply in the same way across societies. ${ }^{17}$ Therefore, I next present cross-level interactions that demonstrate heterogeneous patterns.

\section{[Table-5]}

Table 6 presents cross-level interactions between gender and the predominant religions of countries on a religiosity scale, each of the dogmatism measures individually, and a dogmatism scale. ${ }^{18}$ Gender gaps in religiosity and inverse gaps in religious dogmatism are most prominent in

\footnotetext{
${ }^{16}$ Similar to in the BRS data, gender differences in dogmatism are primarily main effects, although gender gaps again are sometimes larger among the slightly or somewhat religious women and men.

${ }^{17}$ I also examined another item: equal rights for different religious groups. Multinomial logistic regression demonstrated that women are especially likely to be moderate and unlikely to be in the most dogmatic response group on this measure. Because of distribution issues and non-ordered effects, I do not include it with the other measures.

${ }_{18}^{18}$ Bivariate models and models controlling for religion demonstrate similar patterns for interaction effects: gender differences in religiosity are strongest in Christian nations, as are reverse differences in religious dogmatism. Moreover, supplemental models with key country-level controls demonstrated that they were unimportant for the contextuallyvarying gender gaps. Finally, results that separated different Christian countries indicated that although religion in general
} 
Christian nations. The large gender interaction effects for predominant religion on religiousness demonstrate that women are not more religious than men in Turkey (a Muslim country) or Israel (a Jewish country). In fact, the coefficient is reversed in both countries (i.e., men trend toward more religiousness than women), and the reverse gender gap is significant in Israel (see Schnabel et al. 2018). In addition to reversed gender gaps in the Muslim and Jewish countries in the sample, women's comparatively greater religsioty is smaller in the countries where "other Eastern religion" (again, a label created by the ISSP that includes, among others, Taoism and Shintoism) is the majority. The gender gap in the majority-secular countries is similar to that in the Christian countries.

\section{[Table-6]}

Similar but inverse patterns appear for some measures of religious dogmatism: Israeli men are actually more likely than Israeli women to say that all religions should be respected. There is also a significant gender interaction for the "other Eastern" category on whether other religions should be respected. For disapproving of a relative marrying someone of a different faith, there are significant but inverse gender interactions for Israel and the majority unaffiliated countries in the sample. A similar interaction appears in majority unaffiliated countries on disapproving of political candidates of a different religion. Then on the scale constructed from measures fielded in only 20 countries, we see that Turkish men are less likely to have negative views of people in religions different from their own than are Turkish women, and that there are not significant gender differences in the nonreligious countries (the Jewish and "other Eastern" countries did not field these items). Finally, on a scale that includes each of the dogmatism items we see significant interactions for Muslim, "other 
Eastern," and no affiliation with men trending toward less dogmatism in non-Christian contexts (and a similar though not significant interaction for Jewish).

The ISSP is one of the highest-quality sources of cross-national data, but the 40 ISSP countries with relevant data available skew Christian. For example, Turkey is the only predominantly Muslim country in the sample. Regardless of the limitations, the results still demonstrate important differences between Christian and non-Christian nations, and supplemental analyses using Wave 6 of the World Values Survey, which includes more non-Christian countries (but not Israel), confirmed the ISSP patterns and provided similar variance by majority religion: Christian countries in the WVS tend to have large gender gaps with women being more religious, secular countries have gaps similar to Christian countries, Hindu and Buddhist countries smaller gender differences, and Muslim countries tend to demonstrate reverse pattern with men more religious than women. Also consistent with the ISSP data, women in the WVS are less likely than men to say that people in other religions are immoral and less likely to say that their religion is the only acceptable religion.

In short, the results demonstrate that just as gender differences in religiosity are largest in Christian contexts, reverse gender differences in religious dogmatism also tend to be largest in Christian contexts. In other words, where women are more religious, they also tend to be less religiously dogmatic. Israel is a unique case that warrants additional attention in future research, with men more religious and less religiously dogmatic on one measure but more dogmatic on another. Therefore, how women and men "do religion" is not universal, but culture and religion specific.

\section{DISCUSSION}

This study laid out a general theoretical framework-gender differences exist in religion due to the same types of social processes that lead to the gender-typing of other social spheres - and applied it to the question of how women and men “do religion.” Specifically, I examined whether women's greater religiousness is paralleled by more religious dogmatism or whether women's religious beliefs 
and attitudes tend to be more inclusive, compassionate, and tolerant than men's. Confirming my expectations based on gender theory and qualitative research on gender and religion (Avishai 2008; also see Bartkowski and Read 2003; Ecklund 2003; Ozorak 1996; Zion-Waldoks 2015), I found that women and men are doing religion differently and expressing distinctive beliefs and values: women are generally more religious, but often less dogmatic_-at least in Christian contexts. Gender differences in religiosity may therefore be attributable to religion being yet another institutional sphere in which people do gender, so that when doing religion people are also doing gender (Avishai et al. 2015; Cadge 2004; Cornwall 2009; West and Zimmerman 1987; Whitehead 2013). Crossnational variation suggests that just as the general impact of religiousness on attitudes and behavior are culturally specific (Adamczyk and Hayes 2012; Adamczyk and Pitt 2009), gender differences in religiosity and religious dogmatism are not universal, but specific to particular cultural contexts. In Christian contexts, women's religious views are more inclusive and benevolent than men's. For example, American women say people from diverse groups will go to heaven, think that humans are basically good, and believe in a more benevolent divinity, which suggests that women's greater religiosity may be due in part to seeing religion as more comforting and less judgmental. Women across Christian societies, where gender differences tend to be larger, are generally more likely to say that other religions should be respected and to have positive views toward people in religions other than their own. But in non-Christian countries, where gender differences in religiosity tend to be smaller or go in the opposite direction, there are fewer gender differences in dogmatism, and sometimes differences in the opposite direction. For example, Israeli men pray more frequently and are more likely to say all religions should be respected than Israeli women. Religion, therefore, appears to be another sphere in which we face context-specific gender norms and expectations and express our gendered selves. 
Gender differences in religiosity and dogmatism, I argue, result from social processes operating in gendered societies that disadvantage women and expect them to take on roles, identities, and values associated with both care for others and Christian religion (Brenner 2014; Charles and Bradley 2009; Eagly 1987; Trzebiatowska and Bruce 2012). Women fill more caregiving roles (Charles and Bradley 2009; Eagly et al. 2004) and are more responsible for doing spiritual tasks on behalf of their families (Trzebiatowska and Bruce 2012). Conversely, many men are socialized into self-sufficient, individualistic, strong-willed, and sometimes even aggressive masculinities that parallel religious dogmatism and general intolerance (Connell 2005; Greve 2014). Apart from differential socialization (Collett and Lizardo 2009) and the different roles women and men fill (Eagly 1987), people also tend to hold and act upon gender norms-for example, women are assumed to be more communal, expressive, and caring-and thus sanction through social interaction those who do gender transgressively (Edgell et al. 2017; Prentice and Carranza 2002; Rudman and Glick 2001; West and Zimmerman 1987). These gendering processes are then consistent with women's greater overall religiosity and their lower levels of religious dogmatism.

Religions are gendered structures, and a more religious social group is not of necessity more religiously dogmatic and could, instead, perform a more sympathetic "golden rule" religion (Ammerman 1997; Whitehead 2013). Absolutism, intolerance, and possibly religious conflict and violence operate not as inevitable consequences of religiosity, but instead arise at the intersection of masculinity and even moderate religion (Cobb 2006; Macey 1999). This assertion, here based upon attitudinal findings, is corroborated by the gendered nature of religious violence, the "Fight Church" phenomenon, and the notion that despite men's traditional dominance of religious leadership positions Christianity is feminizing and challenging to machismo and similar masculinities worldwide (Cobb 2006; Greve 2014; Kimmel 2003). Future research should explore how gender regimes and religious regimes intersect to produce gendered religious conflict and violence. 
Synthesizing existing theoretical work in the study of gender and qualitative empirical work in the study of religion, I laid out a general framework for quantitative gender differences in religion. In this framework, we can understand gender gaps in religiosity and dogmatism as the result of gender being a social organizing structure, religion being a gendered social structure, and people simultaneously “doing gender" and “doing religion” (Avishai 2008; Martin 2004; Risman 2004; West and Zimmerman 1987). Gender is not just something we are, it is a structure by which society is organized, experienced, and made sense of. Subsequently, gender differences are not simply the result of inherent differences between individual males and females, but are a complex outcome of identities, statuses, and interactions operating within gendered institutional domains. Therefore, gender differences are context-specific and similar processes create and recreate gender differences in different spheres, such as family, work, politics, and, as I argue, religion. As demonstrated by an extensive intersectionality literature, which is just beginning to address the gender differences in religiosity phenomenon (Baker and Whitehead 2016; Schnabel 2016b), social structures are intertwined and identities performed together. What it means to be Black, gay, politically liberal, working class, or a particular religion varies by gender (Crenshaw 1991; Khurshid 2015). Religion is a central, yet often neglected, part of our intersectional selves, and gender differences in religiosity are similar to gender differences in other parts of our lives (Baker and Whitehead 2016; Edgell 2017; Schnabel 2016b). Accordingly, gender differences in religion are not universal but vary across other statuses such as sexuality, class, and race (Schnabel 2016b; Sherkat 2002, 2017), and across religious systems with differently gendered expectations, norms, and incentives (Schnabel et al. 2018).

This study is not without limitations, and I will note a few of the most important ones here. First, the argument that religion is gendered in ways that produce context-specific gender differences may seem obvious to many sociologists of gender, especially those conducting qualitative research on gender and religion. Although it may seem obvious to scholars in some areas, this argument is 
still a key corrective to a large body of quantitative literature on purportedly "universal" gender differences in religiousness. Second, it is hard to measure how women and men "do gender" in religion with survey items, and even harder to do so with existing items in national and crossnational datasets. Therefore, this study measured self-reported religious affect, orientation, and attitudes rather than actual behavior. I expect positive views toward religious others is strongly linked to inclusive interaction with religious others, but do not have data to test this assertion. Third, this study proposed to study a specific concept, religious dogmatism, and had to rely on existing survey data to measure it. I carefully selected the datasets and items used for this study, and I think they provide a good proxy for what I sought to measure. I do, however, hope that future research will further examine religious dogmatism, collecting new data with questions specifically designed to measure it. Fourth, this study synthesized existing work to lay out a larger theoretical framework and applied it to a more specific empirical question, namely whether women and men "do religion" differently in ways expected based on theory about how we "do gender." Future research should further examine this framework empirically. Finally, this study was again limited by the available data and could only examine binary gender differences between women and men. Gender is more complex than a simple binary, and this study's own argument would suggest that gendering processes beyond a binary are important. Future research should include multiple measures of gender, considering, for example, how gradational femininity and masculinity relate to religion within and across gender categories.

Gender difference theories specific to just the religious sphere are incomplete because gender gaps in religion are produced by the same types of social processes that produce gender gaps in other gendered social structures. Politics, family, and work are gendered structures in which people always doing gender, and in which gender gaps can be explained by social processes (Charles and Bradley 2009; Eagly et al. 2004; West and Zimmerman 1987). By the same token, religion is a 
gendered structure in which women and men are always doing gender. I argue that to bring themselves up to date theoretically on gender and religion, religion scholars should incorporate gender scholarship on gender regimes rather than continuing to search for universal differences between women and men (Acker 2006; Martin 2004; Risman 2004; West and Zimmerman 1987; Whitehead 2013). If they were to do so, future research could move beyond the question of just gender differences in religion to higher-level considerations of religion as an intersectional structure. 


\section{REFERENCES}

Acker, Joan. 2006. “Inequality Regimes: Gender, Class, and Race in Organizations.” Gender \& Society 20(4):441-64.

Adamczyk, Amy and Brittany Hayes. 2012. "Religion and Sexual Behaviors: Understanding the Influence of Islamic Cultures and Religious Affiliation for Explaining Sex Outside of Marriage.” American Sociological Review 77(5):723-46.

Adamczyk, Amy and Cassady Pitt. 2009. "Shaping Attitudes about Homosexuality: The Role of Religion and Cultural Context.” Social Science Research 38(2):338-51.

Adorno, Theodor, Else Frenkel-Brunswik, Daniel Levinson, and Nevitt Sanford. 1950. The Authoritarian Personality. Oxford, England: Harpers.

Allport, Gordon and Michael Ross. 1967. "Personal Religious Orientation and Prejudice." Journal of Personality and Social Psychology 5(4):432-43.

Ammerman, Nancy. 1997. "Golden Rule Christianity: Lived Religion in the American Mainstream." Pp. 196-216 in Lived Religion in America, edited by David Hall. Princeton, NJ: Princeton University Press.

Aune, Kristin. 2015. "Feminist Spirituality as Lived Religion: How UK Feminists Forge ReligioSpiritual Lives." Gender \& Society 29(1):122-45.

Avishai, Orit. 2008. "'Doing Religion' in a Secular World: Women in Conservative Religions and the Question of Agency." Gender \& Society 22(4):409-33.

Avishai, Orit. 2016. "Theorizing Gender from Religion Cases: Agency, Feminist Activism, and Masculinity." Sociology of Religion 77(3):261-79.

Avishai, Orit and Courtney Ann Irby. 2017. "Bifurcated Conversations in Sociological Studies of Religion and Gender.” Gender \& Society 31(5):647-76.

Avishai, Orit, Afshan Jafar, and Rachel Rinaldo. 2015. “A Gender Lens on Religion.” Gender \& Society 29(1):5-25.

Baker, Joseph and Andrew Whitehead. 2016. "Gendering (Non)Religion: Politics, Education, and Gender Gaps in Secularity in the United States.” Social Forces 94(4):1623-45.

Bartkowski, John and Jen'nan Ghazal Read. 2003. "Veiled Submission: Gender, Power, and Identity among Evangelical and Muslim Women in the United States." Qualitative Sociology 26(1):71-92.

Beutel, Ann and Margaret Mooney Marini. 1995. "Gender and Values." American Sociological Review 60(3):436-48.

Bonilla-Silva, Eduardo. 1997. "Rethinking Racism: Toward a Structural Interpretation.” American Sociological Review 62(3):465-80.

Box-Steffensmeier, Janet, Suzanna DeBoef, and Tse-min Lin. 2004. "Dynamics of the Partisan Gender Gap." American Political Science Review 98(3):515-28.

Brenner, Philip. 2014. "Testing the Veracity of Self-Reported Religious Practice in the Muslim World." Social Forces 92(3):1009-37.

Cadge, Wendy. 2004. "Gendered Religious Organizations: The Case of Theravada Buddhism in America." Gender \& Society 18(6):777-93.

Charles, Maria and Karen Bradley. 2009. "Indulging Our Gendered Selves? Sex Segregation by Field of Study in 44 Countries." American Journal of Sociology 114(4):924-76.

Cobb, Michael. 2006. God Hates Fags: The Rhetorics of Religious Violence. New York: NYU Press.

Collett, Jessica and Omar Lizardo. 2009. "A Power-Control Theory of Gender and Religiosity." Journal for the Scientific Study of Religion 48(2):213-31.

Connell, Raewyn. 2005. "Hegemonic Masculinity: Rethinking the Concept.” Gender \& Society 19(6):82959.

Converse, Phillip. 1964. "The Nature of Belief Systems in Mass Publics.” in Ideology and Discontent, edited by David Apter. New York: The Free Press. 
Cornwall, Marie. 2009. "Reifying Sex Difference Isn't the Answer: Gendering Processes, Risk, and Religiosity." Journal for the Scientific Study of Religion 48(2):252-55.

Crenshaw, Kimberle. 1991. "Mapping the Margins: Intersectionality, Identity Politics, and Violence against Women of Color.” Stanford Law Review 43(6):1241-99.

Davis, Nancy and Robert Robinson. 1991. "Men's and Women's Consciousness of Gender Inequality." American Sociological Review 56(1):72-84.

Eagly, Alice, Amanda Diekman, Mary Johannesen-Schmidt, and Anne Koenig. 2004. "Gender Gaps in Sociopolitical Attitudes." Journal of Personality and Social Psychology 87(6):796-816.

Eagly, Alice H. 1987. Sex Differences in Social Behavior: A Social-Role Interpretation. Hillsdale, NJ: Lawrence Erlbaum Associates.

Ecklund, Elaine Howard. 2003. "Catholic Women Negotiate Feminism.” Sociology of Religion 64(4):51524.

Edgell, Penny. 2006. Religion and Family in a Changing Society. Princeton, NJ: Princeton University Press.

Edgell, Penny. 2017. "An Agenda for Research on American Religion in Light of the 2016 Election." Sociology of Religion 78(1):1-8.

Edgell, Penny, Jacqui Frost, and Evan Stewart. 2017. "From Existential to Social Understandings of Risk: Examining Gender Differences in Non-Religion." Social Currents 4(6):556-74.

Edgell, Penny, Joseph Gerteis, and Douglas Hartmann. 2006. “Atheists As 'Other': Moral Boundaries and Cultural Membership in American Society." American Sociological Review 71(2):211-34.

Edgell, Penny, Douglas Hartmann, Evan Stewart, and Joseph Gerteis. 2016. "Atheists and Other Cultural Outsiders: Moral Boundaries and the Non-Religious in the United States." Social Forces 95(2):607-38.

Ellis, Lee, Anthony W. Hoskin, and Malini Ratnasingam. 2016. “Testosterone, Risk Taking, and Religiosity: Evidence from Two Cultures." Journal for the Scientific Study of Religion 55(1):153-73.

Francis, Leslie. 1997. "Psychology of Gender Differences in Religion." Religion 27(1):81-96.

Freese, Jeremy. 2004. "Risk Preferences and Gender Differences in Religiousness: Evidence from the World Values Survey." Review of Religious Research 46(1):88-91.

Freese, Jeremy and James Montgomery. 2007. "The Devil Made Her Do It? Evaluating Risk Preference as an Explanation of Sex Differences in Religiousness." Pp. 187-230 in Advances in Group Processes: The Social Psychology of Gender, edited by Shelley Correll. Oxford: Elsevier.

Froese, Paul, Christopher Bader, and Buster Smith. 2008. "Political Tolerance and God's Wrath in the United States." Sociology of Religion 69:29.

Gallagher, Sally. 2003. Evangelical Identity and Gendered Family Life. New Brunswick, NJ: Rutgers University Press.

Gerber, Lynne. 2015. "Grit, Guts, and Vanilla Beans: Godly Masculinity in the Ex-Gay Movement." Gender \& Society 29(1):26-50.

Golebiowska, Ewa A. 1999. "Gender Gap in Political Tolerance.” Political Behavior 21(1):43-66.

Greve, Justine. 2014. “Jesus Didn’t Tap: Masculinity, Theology, and Ideology in Christian Mixed Martial Arts.” Religion and American Culture 24(2):141-85.

Hackett, Conrad, Caryle Murphy, and David McClendon. 2016. The Gender Gap in Religion around the World. Washington, D.C.: Pew Research Center.

Hadler, Markus. 2012. "Influence of World Societal Forces on Social Tolerance." Sociological Quarterly 53(2):211-37.

Hall, Elizabeth Lewis, Kerris Oates, Tamara Anderson, and Michele Willingham. 2012. "Calling and Conflict: Sanctification of Work in Working Mothers." Psychology of Religion and Spirituality 4(1):7183.

Hastings, Orestes P. and D.Michael Lindsay. 2013. "Rethinking Religious Gender Differences: The Case of Elite Women.” Sociology of Religion 74(4):471-95.

Hoffmann, John. 2009. "Gender, Risk, and Religiousness: Can Power Control Provide the Theory?" 
Journal for the Scientific Study of Religion 48(2):232-40.

Hoffmann, John and John Bartkowski. 2008. "Gender, Religious Tradition, and Biblical Literalism." Social Forces 86(3):1245-72.

Hunt, Matthew. 1996. "Individual, Society, or Both? A Comparison of Black, Latino, and White Beliefs about Causes of Poverty." Social Forces 75(1):293-322.

Hyde, Janet Shibley. 2005. “The Gender Similarities Hypothesis.” American Psychologist 60(6):581-92.

Inglehart, Ronald and Pippa Norris. 1999. "The Developmental Theory of the Gender Gap: Women and Men's Voting Behavior in Global Perspective.” International Political Science Review 21(4):441-63.

Khurshid, Ayesha. 2015. "Islamic Traditions of Modernity: Gender, Class, and Islam in a Transnational Women's Education Project.” Gender \& Society 29(1):98-121.

Kimmel, Michael S. 2003. "Globalization and Its Mal(e)Contents: The Gendered Moral and Political Economy of Terrorism.” International Sociology 18(3):603-20.

Levanon, Asaf, Paula England, and Paul Allison. 2009. "Occupational Feminization and Pay: Assessing Causal Dynamics Using 1950-2000 Census Data.” Social Forces 88(2):865-91.

Lizardo, Omar and Jessica L. Collett. 2009. "Rescuing the Baby from the Bathwater: Continuing the Conversation on Gender, Risk, and Religiosity." Journal for the Scientific Study of Religion 48(2):25659.

Macey, Marie. 1999. "Class, Gender and Religious Influences on Changing Patterns of Pakistani Muslim Male Violence in Bradford." Ethnic and Racial Studies 22(5):845-66.

Malka, Ariel, Yphtach Lelkes, Sanjay Srivastava, Adam B. Cohen, and Dale T. Miller. 2012. “The Association of Religiosity and Political Conservatism: The Role of Political Engagement." Political Psychology 33(2):275-99.

Malka, Ariel and Christopher J. Soto. 2011. "The Conflicting Influences of Religiosity on Attitude toward Torture." Personality and Social Psychology Bulletin 37(8):1091-1103.

Malka, Ariel, Christopher J. Soto, Adam B. Cohen, and Dale T. Miller. 2011. "Religiosity and Social Welfare: Competing Influences of Cultural Conservatism and Prosocial Value Orientation." Journal of Personality 79(4):763-92.

Marcuse, Herbert. 1964. One Dimensional Man. Boston, MA: Beacon Press.

Martin, Patricia Yancey. 2004. “Gender As Social Institution.” Social Forces 82(4):1249-73.

Marx, Karl and Freidrich Engels. 2008. On Religion. Mineola, NY: Dover.

Merino, Stephen. 2010. "Religious Diversity in a 'Christian Nation': Effects of Theological Exclusivity and Interreligious Contact on the Acceptance of Religious Diversity." Journal for the Scientific Study of Religion 49:231-46.

Messner, Michael. 2013. "The Masculinity of the Governator: Muscle and Compassion in American Politics." Gender \& Society 21(4):461-80.

Meulemann, Heiner. 2013. "The Two Faces of American Religious Exceptionalism: Religiosity and Dogmatism in the USA and Europe in 2007." Social Compass 60(2):251-72.

Miller, Alan and Rodney Stark. 2002. "Gender and Religiousness: Can Socialization Explanations Be Saved?” American Journal of Sociology 107(6):1399-1423.

Norris, Pippa and Ronald Inglehart. 2011. Sacred and Secular: Religion and Politics Worldwide. 2nd ed. New York: Cambridge University Press.

Olson, Laura, Wendy Cadge, and James Harrison. 2006. "Religion and Public Opinion about Same-Sex Marriage." Social Science Quarterly 87(2):340-60.

Ozorak, Elizabeth Weiss. 1996. "The Power, but Not the Glory: How Women Empower Themselves Through Religion." Journal for the Scientific Study of Religion 35(1):17-29.

Perry, Samuel. 2014. "Hoping for a Godly (White) Family: How Desire for Religious Heritage Affects Whites’ Attitudes Toward Interracial Marriage.” Journal for the Scientific Study of Religion. 53(1):20218.

Powell, Brian, Catherine Bolzendahl, Claudia Geist, and Lala Carr Steelman. 2010. Counted Out: Same- 
Sex Relations and Americans' Definitions of Family. New York: Russell Sage.

Pratto, Felicia, Lisa Stallworth, and Jim Sidanius. 1997. "The Gender Gap: Differences in Political Attitudes and Social Dominance Orientation." British Journal of Social Psychology 36:49-68.

Prentice, Deborah A. and Erica Carranza. 2002. "What Women and Men Should Be, Shouldn't Be, Are Allowed to Be, and Don't Have to Be: The Contents of Prescriptive Gender Stereotypes." Psychology of Women Quarterly 26(4):269-81.

Prickett, Pamela. 2015. "Negotiating Gendered Religious Space: Particularities of Patriarchy in an African American Mosque." Gender \& Society 29(1):51-72.

Putnam, Robert and David Campbell. 2010. American Grace: How Religion Divides and Unites Us. New York: Simon \& Schuster.

Rao, Aliya Hamid. 2015. "Gender and Cultivating the Moral Self in Islam: Muslim Converts in an American Mosque." Sociology of Religion 76(4):413-35.

Reskin, Barbara. 1991. "Labor Markets as Queues: A Structural Approach to Changing Occupational Sex Composition.” Pp. 719-33 in Micro-Macro Linkages in Sociology, edited by Joan Huber. Thousand Oaks, CA: Sage.

Ridgeway, Cecilia L. 2011. Framed by Gender: How Gender Inequality Persists in the Modern World. New York: Oxford University Press.

Risman, Barbara J. 2004. "Gender as a Social Structure.” Gender \& Society 18(4):429-50.

Rokeach, Milton. 1954. “The Nature and Meaning of Dogmatism.” Psychological Review 61(3):194-204.

Rokeach, Milton. 1960. The Open and Closed Mind: Investigations into the Nature of Belief Systems and Personality Systems. New York: Basic Books.

Roth, Louise Marie and Jeffrey Kroll. 2007. "Risky Business: Assessing Risk Preference Explanations for Gender Differences in Religiosity." American Sociological Review 72(2):205-20.

Rudman, Laurie and Peter Glick. 2001. "Prescriptive Gender Stereotypes and Backlash Toward Agentic Women." Journal of Social Issues 57(4):743-62.

Schnabel, Landon. 2015. "How Religious Are American Women and Men? Gender Differences and Similarities." Journal for the Scientific Study of Religion 54(3):616-22.

Schnabel, Landon. 2016a. "Religion and Gender Equality Worldwide: A Country-Level Analysis." Social Indicators Research 129(2):893-907.

Schnabel, Landon. 2016b. "The Gender Pray Gap: Wage Labor and the Religiosity of High-Earning Women and Men." Gender \& Society 30(4):643-69.

Schnabel, Landon. 2017a. "Gendered Religiosity." Review of Religious Research 59(4):547-56.

Schnabel, Landon. 2017b. Opiate of the Masses? Social Inequality, Religion, and Politics. Paper presented at Annual Meetings of the American Sociological Association. Available at https://osf.io/preprints/socarxiv/dnz2w/.

Schnabel, Landon. 2018. "Sexual Orientation and Social Attitudes." Socius 4:1-18.

Schnabel, Landon, Conrad Hackett, and David McClendon. 2018. "Where Men Appear More Religious than Women: Turning a Gender Lens on Religion in Israel." Journal for the Scientific Study of Religion In Press.

Schutz, Amanda and Louise Roth. 2014. "Reconceptualizing Religious Risk: Gender and Atheism.” in Paper Presented at the Annual Meetings of the American Sociological Association.

Sherkat, Darren. 2002. "Sexuality and Religious Commitment in the United States." Journal for the Scientific Study of Religion 41(2):313-23.

Sherkat, Darren. 2017. "Sexuality and Religious Commitment Revisited: Exploring the Religious Commitments of Sexual Minorities from 1991-2014." Journal for the Scientific Study of Religion. Online 1 st.

Sherkat, Darren, Melissa Powell-Williams, Gregory Maddox, and Kylan Mattias de Vries. 2011. "Religion, Politics, and Support for Same-Sex Marriage in the United States, 1988-2008." Social Science Research 40(1):167-80. 
Sherkat, Darren and John Wilson. 1995. "Preferences, Constraints, and Choices in Religious Markets: An Examination of Religious Switching and Apostasy." Social Forces 73(3):993-1026.

Smith, Christian et al. 2013. "Roundtable on the Sociology of Religion: Twenty-Three Theses on the Status of Religion in American Sociology." Journal of the American Academy of Religion 81(4):903-38.

Stouffer, Samuel. 1955. Communism, Conformity, and Civil Liberties: A Cross-Section of the Nation Speaks Its Mind. Garden City, NY: Doubleday.

Sullins, D.Paul. 2006. "Gender and Religion: Deconstructing Universality, Constructing Complexity." American Journal of Sociology 112(3):838-80.

Thompson, Edward. 1991. "Beneath the Status Characteristic: Gender Variations in Religiousness." Journal for the Scientific Study of Religion 30(4):381-94.

Trzebiatowska, Marta and Steve Bruce. 2012. Why Are Women More Religious Than Men? Oxford, UK: Oxford University Press.

de Vaus, David and Ian McAllister. 1987. "Gender Differences in Religion: A Test of the Structural Location Theory." American Sociological Review 52(4):472-81.

Walter, Tony and Grace Davie. 1998. "Religiosity of Women in the Modern West." British Journal of Sociology 49(4):640-60.

Weber, Max. 1963. The Sociology of Religion. edited by Ephraim Fischoff. Boston: Beacon Press.

West, Candace and Don H. Zimmerman. 1987. "Doing Gender." Gender \& Society 1(2):125-51.

Whitehead, Andrew. 2013. "Gendered Organizations and Inequality Regimes." Journal for the Scientific Study of Religion 52(3):476-93.

Winter, Nicholas. 2010. "Masculine Republicans and Feminine Democrats: Gender and Americans' Explicit and Implicit Images of the Political Parties." Political Behavior 32:587-618.

Zion-Waldoks, Tanya. 2015. "Politics of Devoted Resistance: Agency, Feminism, and Religion among Orthodox Agunah Activists in Israel." Gender \& Society 29(1):73-97. 
More Religious, Less Dogmatic 30

\section{TABLES AND FIGURES}

Table 1: Baylor Religion Survey Descriptive Statistics

\begin{tabular}{|c|c|c|c|c|c|}
\hline Measures & Descriptions & $N$ & Mean & $S D$ & Range $^{\mathbf{a}}$ \\
\hline \multicolumn{6}{|l|}{ Dependent Variables } \\
\hline \multicolumn{6}{|l|}{ Typical Religion Measures } \\
\hline Religious Affiliation & Affiliated $=1$ & 1,598 & .89 & & \\
\hline Religious Salience & Not at All Religious $=1$, Very Religious $=4$ & 1,602 & 2.96 & .95 & $1.06-3.81$ \\
\hline Attendance Frequency & Never $=1$, Several Times a Week $=9$ & 1,623 & 4.80 & 2.90 & $.54-9.62$ \\
\hline Prayer Frequency & Never $=1$, Several Times a Day $=6$ & 1,632 & 4.09 & 1.77 & $.98-5.83$ \\
\hline Belief in Heaven & Absolutely Not=1, Absolutely Exists=4 & 1,603 & 3.33 & .98 & $1.53-4.08$ \\
\hline View of Bible & Ancient Book=1, Literal Word of God $=4$ & 1,511 & 2.55 & 1.11 & $1.25-4.28$ \\
\hline Religiosity Scale & Standardized Religiosity Scale, $a=.88$ & 1,646 & 0.00 & 1.00 & $-2.54-1.45$ \\
\hline \multicolumn{6}{|l|}{ Afterlife Exclusivity } \\
\hline Neighbors & All Go to Heaven $=0$, None $\mathrm{Go}=4$ & 991 & 1.55 & 1.04 & $.39-6.75$ \\
\hline Average Americans & All Go to Heaven $=0$, None $\mathrm{Go}=4$ & 1,006 & 1.57 & 1.03 & $-.09-4.21$ \\
\hline Buddhists & All Go to Heaven $=0$, None $\mathrm{Go}=4$ & 866 & 1.89 & 1.44 & $.72-4.11$ \\
\hline Muslims & All Go to Heaven $=0$, None $\mathrm{Go}=4$ & 866 & 2.05 & 1.44 & $.55-4.24$ \\
\hline Jews & All Go to Heaven $=0$, None $\mathrm{Go}=4$ & 901 & 1.55 & 1.21 & $.39-4.37$ \\
\hline Non-Religious & All Go to Heaven=0, None $\mathrm{Go}=4$ & 898 & 2.34 & 1.45 & $.7 .-3.81$ \\
\hline Afterlife Scale & Standardized Afterlife Scale, $a=.93$ & 1,127 & 0.00 & 1.00 & $-1.93-4.36$ \\
\hline \multicolumn{6}{|l|}{ Religious Identity } \\
\hline Fundamentalist & Not at All $=1$, Describes Self Very Well $=4$ & 1,300 & 1.63 & .97 & $1.01-3.96$ \\
\hline Religious Right & Not at All=1, Describes Self Very Well $=4$ & 1,272 & 1.62 & 1.01 & $1.04-4.41$ \\
\hline Theological Conservative & Not at All $=1$, Describes Self Very Well $=4$ & 1,281 & 2.01 & 1.15 & $1.00-3.88$ \\
\hline Identity Scale & Standardized Identity Scale, $a=.79$ & 1,422 & 0.00 & 1.00 & $-1.03-3.12$ \\
\hline \multicolumn{6}{|l|}{ View of God } \\
\hline Punishing God & Strongly Disagree $=1$, Strongly Agree $=4$ & 1,304 & 2.28 & 1.12 & $1.23-4.25$ \\
\hline Angry God & Strongly Disagree $=1$, Strongly Agree $=4$ & 1,255 & 2.83 & 1.04 & $1.06-3.85$ \\
\hline Severe God & Strongly Disagree $=1$, Strongly Agree $=4$ & 1,277 & 1.98 & 1.07 & $1.20-4.23$ \\
\hline Wrathful God & Strongly Disagree $=1$, Strongly Agree $=4$ & 1,281 & 2.04 & 1.10 & $1.14-4.21$ \\
\hline Terrible-Woe-Giving God & Strongly Disagree $=1$, Strongly Agree $=4$ & 1,319 & 1.93 & .76 & $1.46-4.75$ \\
\hline Small-Punishments God & Strongly Disagree $=1$, Strongly Agree $=4$ & 1,313 & 1.91 & .76 & $1.56-4.19$ \\
\hline War-Requiring God & Strongly Disagree $=1$, Strongly Agree $=4$ & 1,271 & 2.16 & .99 & $.87-3.85$ \\
\hline Tragedy-Allowing God & Strongly Disagree $=1$, Strongly Agree $=4$ & 1,282 & 2.32 & 1.01 & $.83-3.74$ \\
\hline Tragedy-Causing God & Strongly Disagree $=1$, Strongly Agree $=4$ & 1,273 & 1.84 & .85 & $.92-3.90$ \\
\hline View of God Scale & Standardized View of God Scale, $a=.87$ & 1,480 & 0.00 & 1.00 & $-2.32-5.12$ \\
\hline Dogmatism Scale & Standardized Dogmatism Scale, $a=.93$ & 1,615 & 0.00 & 1.00 & $-2.54-3.76$ \\
\hline \multicolumn{6}{|l|}{ Key Independent Variable } \\
\hline Woman & Woman=1 & 1,648 & .55 & & \\
\hline \multicolumn{6}{|l|}{ Sociodemographic Controls } \\
\hline Age & In Years & 1,648 & 50.95 & 16.42 & $18-96$ \\
\hline Parental Status & 1 Or More Children $=1$ & 1,648 & .75 & & \\
\hline Marital Status & Married=1 & 1,648 & .67 & & \\
\hline Rural & Residence in Rural Location $=1$ & 1,648 & .21 & & \\
\hline South & Region is South $=1$ & 1,648 & .31 & & \\
\hline \multicolumn{6}{|l|}{ Education } \\
\hline$<$ High School & Less Than High School=1 & 1,648 & .07 & & \\
\hline High School & High School=1 & 1,648 & .23 & & \\
\hline Some College/Junior College & Some College/Junior College $=1$ & 1,648 & .32 & & \\
\hline Bachelor & Bachelor $=1$ & 1,648 & .20 & & \\
\hline Postgraduate Work/Degree & Postgraduate Work/Degree $=1$ & 1,648 & .19 & & \\
\hline \multicolumn{6}{|l|}{ Religious Salience Covariate } \\
\hline Not at All Religious & Not at All Religious $=1$ & 1,648 & .11 & & \\
\hline Not too Religious & Not too Religious $=1$ & 1,648 & .15 & & \\
\hline Somewhat Religious & Somewhat Religious $=1$ & 1,648 & .42 & & \\
\hline Very Religious & Very Religious $=1$ & 1,648 & .32 & & \\
\hline
\end{tabular}

Source: Baylor Religion Survey 2007

${ }^{a}$ Range shows the highest and lowest values from the alternate least squares optimized scaling. The individual point values are updated to better match the real distance between categories, but the mean and standard deviation remain the same as the pre-optimized measures. 
More Religious, Less Dogmatic 31

Table 2: International Social Survey Programme Descriptive Statistics

\begin{tabular}{|c|c|c|c|c|c|}
\hline Measures & Descriptions & $N$ & Mean & $S D$ & Range \\
\hline \multicolumn{6}{|l|}{ Dependent Variables } \\
\hline \multicolumn{6}{|l|}{ Typical Religion Measures } \\
\hline Religious Affiliation & Affiliated $=1$ & 59,208 & .79 & & \\
\hline Religious Salience & Extremely Non-Religious $=1$, Extremely Religious $=7$ & 58,438 & 4.23 & 1.52 & $1.91-6.79$ \\
\hline Attendance Frequency & Never $=1$, Several Times a Week $=8$ & 57,231 & 3.74 & 2.31 & $1.27-7.71$ \\
\hline Prayer Frequency & Never $=1$, Several Times a Day $=11$ & 58,869 & 5.59 & 3.75 & $1.16-11.15$ \\
\hline Belief in an Afterlife & No, Definitely Not $=1$, Yes, definitely $=4$ & 54,157 & 2.67 & 1.13 & $1.47-4.24$ \\
\hline Religiosity Scale & Standardized Religosity Scale, $a=.82$ & 59,943 & 0.00 & 1.00 & $-2.29-2.08$ \\
\hline \multicolumn{6}{|c|}{ Lack of Respect and Acceptance for Other Religions } \\
\hline Not Respect All Religions & Strongly Disagree $=1$, Strongly Agree $=5$ & 58,166 & 1.99 & 1.01 & $1.38-6.42$ \\
\hline Reject Other Religion Marriage & Definitely Accept=1, Definitely Not Accept $=4$ & 56,038 & 1.95 & .94 & $1.12-4.16$ \\
\hline Reject Other Religion Political Candidate & Definitely Accept $=1$, Definitely Not Accept $=4$ & 54,019 & 1.91 & .89 & $1.03-4.02$ \\
\hline Dislike People in Other Religions Scale ${ }^{\mathrm{a}}$ & Very Positive to Very Negative, $a=.92$ & 28,643 & 0.00 & 1.00 & $-2.20-2.48$ \\
\hline Dogmatism Scale & Standardized Dogmatism Scale, $a=.63$ & 59,455 & 0.00 & 1.00 & $-2.79-5.77$ \\
\hline \multicolumn{6}{|l|}{ Key Independent Variable } \\
\hline Woman & Woman $=1$ & 59,970 & .55 & & \\
\hline \multicolumn{6}{|l|}{ Sociodemographic Controls } \\
\hline Age & In Years & 59,970 & 46.65 & 17.37 & $15-98$ \\
\hline Marital Status & Married $=1$ & 59,970 & .54 & & \\
\hline \multicolumn{6}{|l|}{ Education } \\
\hline No Formal Qualification & No Formal Qualification=1 & 59,970 & .09 & & \\
\hline Lowest Formal Qualification & Lowest Formal Qualification $=1$ & 59,970 & .14 & & \\
\hline Above Lowest Qualification & Above Lowest Qualification=1 & 59,970 & .21 & & \\
\hline Higher Secondary Completed & Higher Secondary Completed $=1$ & 59,970 & .25 & & \\
\hline Above Higher Secondary & Above Higher Secondary $=1$ & 59,970 & .15 & & \\
\hline University Degree Completed & University Degree Completed=1 & 59,970 & .16 & & \\
\hline Religious Salience Imputed Covariate & Extremely Non-Religious $=1$, Extremely Religious $=7$ & 59,970 & 4.22 & 1.52 & $1-7$ \\
\hline
\end{tabular}

Source: International Social Survey Programme 2008

${ }^{a}$ These questions were only fielded in 20 countries, and the sample was restricted to those being asked about a religion different from their own. 
Table 3: Gender Differences (Woman=1) on Measures Similar to Those Used in Previous Studies on Gender Differences in Religiosity, Baylor Religion Survey

\begin{tabular}{|c|c|c|c|c|c|}
\hline \multirow[b]{2}{*}{ Measures } & \multirow[b]{2}{*}{$N$} & \multicolumn{2}{|c|}{ Bivariate } & \multicolumn{2}{|c|}{$\begin{array}{c}\text { Socio- } \\
\text { demographics }\end{array}$} \\
\hline & & $B$ & $S E$ & $\boldsymbol{B}$ & $S E$ \\
\hline Religious Affiliation & 1,598 & $.62^{* * *}$ & .16 & $.62^{* * * *}$ & .17 \\
\hline Religious Salience & 1,602 & $.27^{* * *}$ & .05 & $.26^{* * * *}$ & .05 \\
\hline Attendance Frequency & 1,623 & $.67^{* * *}$ & .14 & $.65^{* * *}$ & .14 \\
\hline Prayer Frequency & 1,632 & $.81^{* * *}$ & .09 & $.79^{* * *}$ & .08 \\
\hline Belief in Heaven & 1,603 & $.30^{* * *}$ & .05 & $.28^{* * *}$ & .05 \\
\hline View of Bible & 1,511 & $.27^{* * *}$ & .06 & $.23^{* * *}$ & .05 \\
\hline Standardized Religiosity Scale & 1,646 & $.35^{* * *}$ & .05 & $.33^{* * *}$ & .05 \\
\hline
\end{tabular}

Source: Baylor Religion Survey 2007

Note: ALSOS used for all but affiliation, for which logistic regression was used. The sociodemographic models include controls for age, race, parental status, marital status, rural residence, region, and education.

${ }^{*} p<0.05,{ }^{* *} p<0.01,{ }^{* * *} p<0.001$ (two-tailed) 
Table 4: Gender Differences (Woman=1) on Measures of Religious Dogmatism, Baylor Religion Survey

\begin{tabular}{|c|c|c|c|c|c|c|c|}
\hline \multirow[b]{2}{*}{ Measures } & \multirow[b]{2}{*}{$N$} & \multicolumn{2}{|c|}{ Bivariate } & \multicolumn{2}{|c|}{$\begin{array}{c}\text { Socio- } \\
\text { demographics }\end{array}$} & \multicolumn{2}{|c|}{$\begin{array}{c}\text { Socio- } \\
\text { Demographics } \\
\text { and Religious } \\
\text { Salience } \\
\end{array}$} \\
\hline & & $\boldsymbol{B}$ & $S E$ & B & $S E$ & B & $S E$ \\
\hline \multicolumn{8}{|l|}{ Afterlife Exclusivity } \\
\hline Neighbors & 991 & $-.26^{* * *}$ & .07 & $-.26^{* * *}$ & .07 & $-.28^{* * *}$ & .07 \\
\hline Average Americans & 1,006 & $-.24^{* * * *}$ & .06 & $-.25^{* * *}$ & .07 & $-.28^{* * *}$ & .07 \\
\hline Buddhists & 866 & $-.20^{*}$ & .10 & $-.22^{*}$ & .10 & $-.32^{* * *}$ & .09 \\
\hline Muslims & 866 & $-.28^{* *}$ & .10 & $-.31^{* *}$ & .10 & $-.41^{* * *}$ & .09 \\
\hline Jews & 901 & $-.25^{* *}$ & .08 & $-.27^{* * *}$ & .08 & $-.33^{* * *}$ & .08 \\
\hline Non-Religious & 898 & -.09 & .10 & -.12 & .10 & $-.22^{*}$ & .09 \\
\hline Afterlife Scale & 1,127 & $-.17^{* *}$ & .06 & $-.18^{* *}$ & .06 & $-.24^{* * *}$ & .06 \\
\hline \multicolumn{8}{|l|}{ Religious Identity } \\
\hline Fundamentalist & 1,300 & -.00 & .05 & -.02 & .05 & $-.11^{*}$ & .05 \\
\hline Religious Right & 1,272 & .00 & .12 & -.02 & .06 & $-.12^{*}$ & .05 \\
\hline Theological Conservative & 1,281 & .02 & .06 & -.00 & .06 & $-.14^{*}$ & .06 \\
\hline Dogmatic Identity Scale & 1,422 & .00 & .05 & -.01 & .05 & $-.13^{* *}$ & .05 \\
\hline \multicolumn{8}{|l|}{ View of God } \\
\hline Punishing God & 1,304 & $-.24^{* * * *}$ & .06 & $-.26^{* * *}$ & .06 & $-.32^{* * * *}$ & .06 \\
\hline Angry God & 1,255 & .02 & .06 & -.01 & .06 & $-.11^{*}$ & .05 \\
\hline Severe God & 1,277 & $-.25^{* * * *}$ & .06 & $-.26^{* * *}$ & .06 & $-.30^{* * *}$ & .06 \\
\hline Wrathful God & 1,281 & $-.16^{* *}$ & .06 & $-.18^{* *}$ & .06 & $-.24^{* * *}$ & .06 \\
\hline Terrible-Woe-Giving God & 1,319 & $-.10^{*}$ & .04 & $-.12^{* *}$ & .04 & $-.14^{* * *}$ & .04 \\
\hline Small-Punishments God & 1,313 & $-.09^{*}$ & .04 & $-.10^{*}$ & .04 & $-.12^{* *}$ & .04 \\
\hline War-Requiring God & 1,271 & -.02 & .06 & -.05 & .05 & $-.11^{*}$ & .05 \\
\hline Tragedy-Allowing God & 1,282 & .02 & .06 & -.00 & .06 & -.08 & .05 \\
\hline Tragedy-Causing God & 1,273 & $-.10^{*}$ & .05 & $-.11^{*}$ & .05 & $-.15^{* * *}$ & .05 \\
\hline View of God Scale & 1,480 & $-.12^{*}$ & .05 & $-.14^{* *}$ & .05 & $-.22^{* * *}$ & .05 \\
\hline Dogmatism Scale & 1,615 & $-.11^{*}$ & .05 & $-.13^{* *}$ & .05 & $-.26^{* * *}$ & .04 \\
\hline
\end{tabular}

Source: Baylor Religion Survey 2007

Note: ALSOS used for all outcomes. The sociodemographic models include controls for age, race, parental status, marital status, rural residence, region, and education. The religious salience models add a measure of religious salience with sociodemographic characteristics also included.

${ }^{*} p<0.05,{ }^{* *} p<0.01,{ }^{* * *} p<0.001$ (two-tailed) 
Table 5: Gender Differences (Woman=1) on Measures of Religiosity and Religious Dogmatism, International Social Survey Programme

\begin{tabular}{|c|c|c|c|c|c|c|c|}
\hline \multirow[b]{2}{*}{ Measures } & \multirow[b]{2}{*}{$N$} & \multicolumn{2}{|c|}{ Bivariate } & \multicolumn{2}{|c|}{$\begin{array}{c}\text { Socio- } \\
\text { demographics }\end{array}$} & \multicolumn{2}{|c|}{$\begin{array}{c}\text { Socio- } \\
\text { Demographics } \\
\text { and Religious } \\
\text { Salience } \\
\end{array}$} \\
\hline & & $\boldsymbol{B}$ & $S E$ & $\boldsymbol{B}$ & $S E$ & B & $S E$ \\
\hline \multicolumn{8}{|l|}{ Religiosity } \\
\hline Religious Affiliation & 59,208 & $.52^{* * *}$ & .02 & $.54^{* * *}$ & .02 & - & - \\
\hline Religious Salience & 58,438 & $.37^{* * *}$ & .01 & $.38^{* * *}$ & .01 & - & - \\
\hline Attendance Frequency & 57,231 & $.45^{* * *}$ & .02 & $.45^{* * *}$ & .02 & $.13^{* * *}$ & .02 \\
\hline Prayer Frequency & 58,869 & $1.28^{* * *}$ & .03 & $1.29^{* * * *}$ & .03 & $.79^{* * *}$ & .02 \\
\hline Belief in an Afterlife & 54,157 & $.27^{* * *}$ & .01 & $.27^{* * * *}$ & .01 & $.15^{* * *}$ & .01 \\
\hline Religiosity Scale & 59,943 & $.31^{* * *}$ & .01 & $.32^{* * *}$ & .01 & - & - \\
\hline \multicolumn{8}{|l|}{ Religious Dogmatism } \\
\hline Not Respect All Religions & 58,166 & $-.08^{* * *}$ & .01 & $-.08^{* * *}$ & .01 & $-.06^{* * *}$ & .01 \\
\hline Reject Other Religion Marriage & 56,038 & $-.02^{*}$ & .01 & $-.02^{*}$ & .01 & $-.03^{* * *}$ & .01 \\
\hline Reject Other Religion Candidate & 54,019 & .00 & .01 & .00 & .01 & -.01 & .01 \\
\hline Dislike Other Religions (Scale) & 28,643 & $-.05^{* * *}$ & .01 & $-.05^{* * *}$ & .01 & $-.03^{* *}$ & .01 \\
\hline Dogmatism Scale & 59,455 & $-.05^{* * * *}$ & .01 & $-.05^{* * * *}$ & .01 & $-.04^{* *}$ & .01 \\
\hline
\end{tabular}

Source: International Social Survey 2008

Note: ALSOS mixed-effects multi-level models used for all outcomes except religious affiliation, for which logistic mixed-effects regression was used, and the scales, for which linear mixed-effects multi-level regression was used. The bivariate models include country-level majority religion. Sociodemographic models add controls for age, marital status, and education. The religious salience models add a continuous variable for religious salience. ${ }^{*} p<0.05,{ }^{* *} p<0.01,{ }^{* * *} p<0.001$ (two-tailed) 
Table 6: Cross-Level Interactions of Gender and Country's Predominant Religion on Key Religiosity and Dogma Measures, International Social Survey Programme

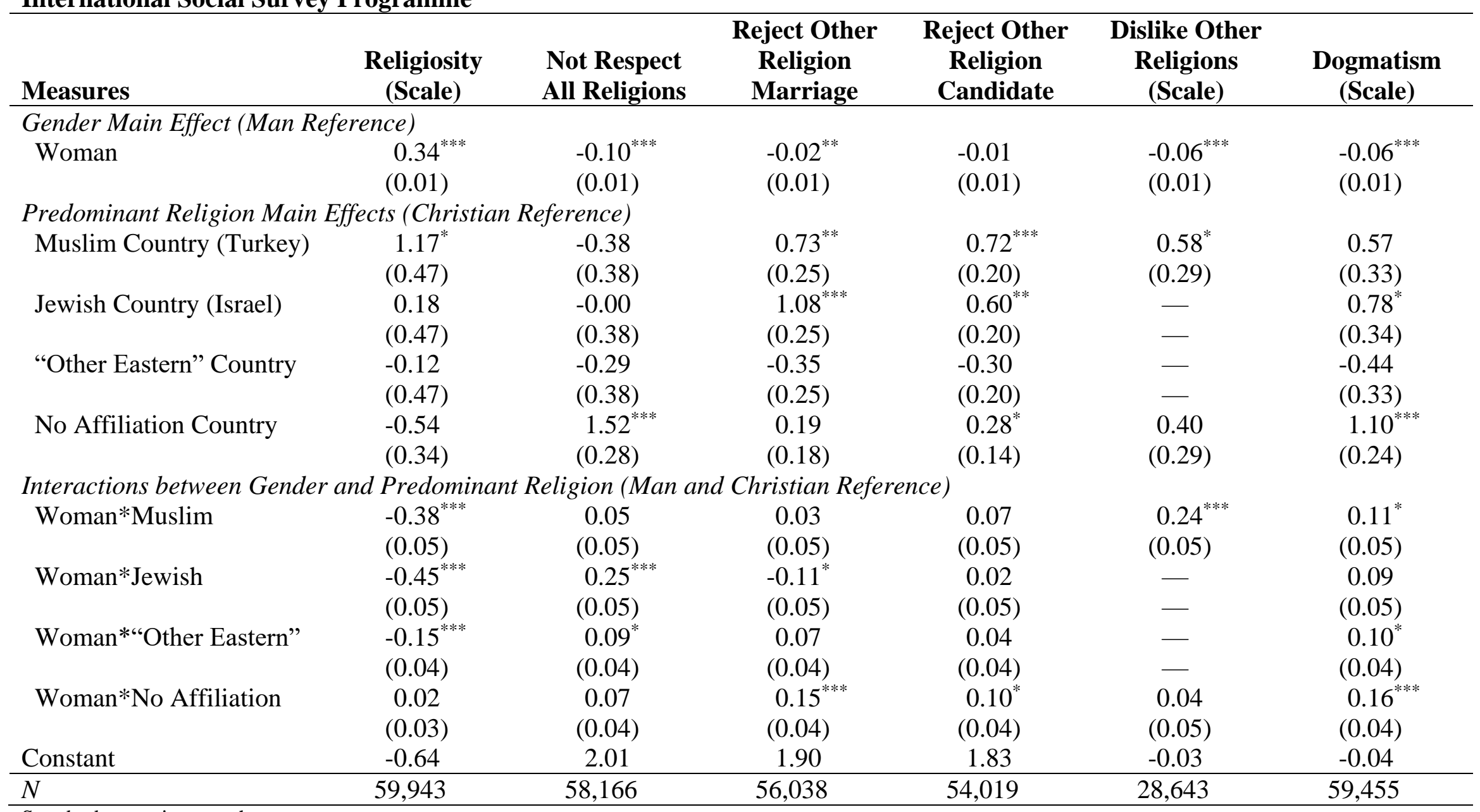

Standard errors in parentheses

Source: International Social Survey 2008

Note: ALSOS mixed-effects multi-level models used for individual outcomes and linear mixed-effects multi-level regression for the scales. All models include age, marital status, and education. ${ }^{*} p<0.05,{ }^{* *} p<0.01,{ }^{* * *} p<0.001$ 
Table A1: Gender Differences (Woman=1) in Progressive Religious Identity and Belief in a Loving God, Baylor Religion Survey

\begin{tabular}{|c|c|c|c|c|c|c|c|}
\hline \multirow[b]{2}{*}{ Measures } & \multirow[b]{2}{*}{$N$} & \multicolumn{2}{|c|}{ Bivariate } & \multicolumn{2}{|c|}{$\begin{array}{c}\text { Socio- } \\
\text { demographics }\end{array}$} & \multicolumn{2}{|c|}{$\begin{array}{c}\text { Socio- } \\
\text { Demographics } \\
\text { and Religious } \\
\text { Salience } \\
\end{array}$} \\
\hline & & $B$ & $S E$ & $B$ & $S E$ & B & $S E$ \\
\hline \multicolumn{8}{|l|}{ Religious Identity } \\
\hline Religious Left & 1,252 & .04 & .05 & .06 & .05 & .04 & .05 \\
\hline Theological Liberal & 1,257 & $.11^{*}$ & .05 & $.14^{*}$ & .05 & $.12^{*}$ & .05 \\
\hline \multicolumn{8}{|l|}{ View of God } \\
\hline Loving & 1,363 & $.22^{* * * *}$ & .04 & $.21^{* * * *}$ & .04 & $.14^{* * *}$ & .04 \\
\hline Kind & 1,356 & $.25^{* * *}$ & .04 & $.23^{* * *}$ & .04 & $.16^{* * *}$ & .04 \\
\hline Friendly & 1,314 & $.17^{* * *}$ & .05 & $.15^{* * *}$ & .05 & $.09^{*}$ & .04 \\
\hline Forgiving & 1,400 & $.18^{* * *}$ & .04 & $.17^{* * *}$ & .04 & $.11^{* *}$ & .04 \\
\hline Concerned with Wellbeing & 1,323 & $.28^{* * *}$ & .05 & $.27^{* * *}$ & .05 & $.17^{* * * *}$ & .04 \\
\hline
\end{tabular}

Source: Baylor Religion Survey 2007

Note: OLS used for all outcomes. The sociodemographic models include controls for age, race, parental status, marital status, rural residence, region, and education. The religious salience models add a measure of religious salience with sociodemographic characteristics also included.

${ }^{*} p<0.05,{ }^{* *} p<0.01,{ }^{* * *} p<0.001$ (two-tailed) 
Table A2: Gender Differences in Political Orientation (Extremely Conservative=1 to Extremely Liberal=7) Before and After Accounting for Religiousness and Dogmatism, Baylor Religion Survey

\begin{tabular}{lcccc}
\hline Measures & Model 1 & Model 2 & Model 3 & Model 4 \\
\hline Woman & $.33^{* * *}$ & $.55^{* * *}$ & $.23^{* *}$ & $.40^{* * * *}$ \\
& $(.08)$ & $(.07)$ & $(.07)$ & $(.07)$ \\
Religiousness & & $-.69^{* * *}$ & & $-.42^{* * *}$ \\
& & $(.04)$ & & $(.04)$ \\
Religious Dogmatism & & & $-.70^{* * *}$ & $-.48^{* * *}$ \\
& & & $(.04)$ & $(.04)$ \\
Sociodemographic Controls & Yes & Yes & Yes & Yes \\
Constant & 4.50 & 3.87 & 4.51 & 4.13 \\
\hline$N$ & 1,566 & 1,566 & 1,566 & 1,566 \\
\hline
\end{tabular}

Source: Baylor Religion Survey 2007

Standard errors in parentheses

Note: OLS used for all outcomes. Sociodemographic controls include age, race, parental status, marital status, rural residence, region, and education.

${ }^{*} p<0.05,{ }^{* *} p<0.01,{ }^{* * *} p<0.001$ (two-tailed) 